\title{
Are the current IHS guidelines for migraine drug trials being followed?
}

\author{
Anders Hougaard · Peer Tfelt-Hansen
}

Received: 29 June 2010/ Accepted: 12 September 2010/Published online: 8 October 2010

(C) Springer-Verlag 2010

\begin{abstract}
In 2000, the Clinical Trials Subcommittee of the International Headache Society (IHS) published the second edition of its guidelines for controlled trials of drugs in migraine. The purpose of this publication was to improve the quality of such trials by increasing the awareness amongst investigators of the methodological issues specific to this particular illness. Until now the adherence to these guidelines has not been systematically assessed. We reviewed all published controlled trials of drugs in migraine from 2002 to 2008. Eligible trials were scored for compliance with the IHS guidelines by using grading scales based on the most essential recommendations of the guidelines. The primary efficacy measure of each trial was also recorded. A total of 145 trials of acute treatment and 52 trials of prophylactic treatment were eligible for review. Of the randomized, double-blind trials, acute trials scored an average of 4.7 out of 7 while prophylactic trials scored an average of 5.6 out of 9 for compliance. Thirty-one percent of acute trials and $72 \%$ of prophylactic trials used the recommended primary efficacy measure. Fourteen percent of the reviewed trials were either not randomized or not double-blinded. Adherence to international guidelines like these of IHS is important to ensure that only high-quality trials are performed, and to provide the consensus that is required for meta analyses. The primary efficacy measure for trials of acute treatment should be "pain free" and not "headache relief". Openlabel or non-randomized trials generally have no place in the study of migraine drugs.
\end{abstract}

A. Hougaard · P. Tfelt-Hansen ( $\square)$

Department of Neurology, Danish Headache Centre, Glostrup Hospital, University of Copenhagen, 2600 Glostrup, Denmark e-mail: ptha@glo.regionh.dk
Keywords Migraine - Randomised clinical trials - Acute treatment $\cdot$ Prophylactic treatment $\cdot$ Efficacy parameters

\section{Introduction}

The last major breakthrough in acute migraine treatment was the introduction of the triptans in the beginning of the 1990s. The triptans have now become the gold standard for acute migraine therapy [1] although their superiority over analgesics has been questioned [2]. However, not all patients respond to triptans [3] and triptans are used only by a minority $(10-15 \%)$ of migraine patients $[4,5]$. The triptans have, thus, probably not reduced migraine-related abeseteeism and socio-economic costs [6].

No currently marketed drug has been developed specifically for the prevention of migraine. Several drugs have, however, been shown to effectively reduce attack frequency in some patients, but these drugs are often associated with adverse effects that can be intolerable [7]. Thus, there is a large need for developing new therapies for the treatment of migraine.

In recent years, several candidates for pharmacological treatment of migraine has been discovered, such as CGRP-antagonists [8], NOS-inhibitors [9] and tonabersat $[10,11]$. As a consequence, a large number of clinical trials in migraine are currently being carried out and many more will be carried out in the years to come. Possibly these studies will show new substances to be more effective and better tolerable in comparison with current treatments.

In order for the multi-million dollar investments going into these trials to truly benefit the migraineurs and in the end reduce the global burden of migraine, it must be ensured that the trials are internally and externally valid 
and that publication bias [12] does not take place. Also, to allow for comparison of trial outcomes and an international collaboration on drug development and therapy for migraine, there must, at least to some extent, be a global agreement on trial design and the parameters used for the assessment of efficacy, adverse events and safety.

In order to address these specific methodological problems and to generally improve the quality of migraine trials the Clinical Trials Subcommittee of the International Headache Society (IHS) published the first edition of its guidelines for controlled trials of drugs in migraine in 1991 [13].These guidelines consist of a series of recommendations, with comments, for the selection of patients, trial design, evaluation of results and the use of statistics. The second edition of these guidelines was published in 2000 [14], amongst other changes introducing additional recommendations for efficacy measures in acute trials.

In 2007, The European Medicines Agency published Guidelines on Clinical Investigation of Medicinal Products for the Treatment of migraine [15] and these guidelines are mainly based on the IHS guidelines with the same primary efficacy parameters.

Thus, these recommendations have been widely elaborated and disseminated but it has not been systematically assessed to what extent they are actually followed by investigators.

The objective of this review was to assess to what extent clinical drug trials in migraine carried out from 2002 until 2008 followed the 2000 IHS guidelines.

\section{Methods}

Criteria for considering studies for this review

Studies were required to be prospective controlled trials of pharmacological interventions for the treatment of migraine attacks, either acute treatment or preventive treatment. Migraine could be with and/or without aura, special types of migraine or unspecified.

Study participants were required to be adults (aged 18 years or older).

The publication dates for the studies were between 2002 and 2008 , both years inclusive.

The following were excluded from the review:

- Studies of combined pharmacological and non-pharmacological treatment.

- Studies reported only in languages other than English, German, Swedish, Norwegian or Danish.

- Studies not concerning migraine exclusively (e.g. migraine and tension-type headache or migraine and depression).
- Studies of pharmacokinetics and/or pharmacodynamics exclusively.

- Studies of safety and tolerability exclusively.

- Studies with non-clinical outcome measures only (e.g. blood samples, MRI, EEG).

- Studies of induced migraine.

Search methods

PubMed was searched using the Cochrane Highly Sensitive Search Strategy (HSSS) for PubMed (as revised 2008) [16] and with publication date limits ranging from January 1, 2002 until December 31, 2008. The entire search string thus being: “'2002/01/01'[Publication Date]: '2008/12/ 31'[Publication Date] AND (migraine AND (randomized controlled trial OR randomized OR placebo OR drug therapy OR randomly OR trial OR groups) NOT animals NOT (humans and animals))".

The Cochrane Central Register of Controlled Trials (CENTRAL) was searched using the word "migraine".

Clinicaltrials.gov was searched using the word "migraine" and with the following criteria: "Study type: Interventional studies", "Age group: Adult (18-65) and Senior (66+)".

Furthermore, trials were identified by searching reference lists of review articles.

Eligibility

Titles and abstracts of studies identified by the literature search were screened for eligibility. Papers that could not be excluded with certainty on the basis of information contained in the title and/or abstract were retrieved in full for screening.

Data extraction and analysis

Trials were divided into trials dealing with acute treatment and trials dealing with prophylactic treatment.

Of the various points of recommendations listed in the 2000 IHS guidelines some are optional and some only apply to special types of trials. Only a few can be regarded as generally essential.

For the evaluation of the trials in this review simplified version of the guidelines were developed containing only the recommendations which were deemed essential and presented in an unambiguous way which allows for clear judgment of whether the trial follows the guidelines on each point.

Based on this simplified version of the guidelines two schedules for the evaluation of drug trials dealing with acute and prophylactic treatment, respectively, were developed in 
which a trial is assigned one point for each guideline requirement met and 0 for each of those that are not. The evaluation schedules are shown in Table 1,2 .

In addition, the following were registered for each trial: publication date, size (number of treated patients),

Table 1 Schedules for evaluation of clinical trials in migraine

Acute

Selection of patients

Do the diagnostic criteria conform to those of the IHS? $(+1 /+0)$

Trial design

Is the trial double blind? $(+1 /+0)$

Is the trial placebo-controlled? $(+1 /+0)$

Were the trial participants randomized at entry to the trial? $(+1 /+0)$

Evaluation of results

IHS recommended

Is the percentage of patients pain-free at $2 \mathrm{~h}$ used as a primary measure of efficacy? $(+1 /+0)$

Is sustained pain-free (percentage of patients pain-free within $2 \mathrm{~h}$ with no use of rescue medication or relapse within $48 \mathrm{~h}$ ) used as a measure of efficacy? $(+1 /+0)$

Is "headache relief" (percentage of patients with a decrease in headache from severe or moderate to none or mild within $2 \mathrm{~h}$ before any rescue medication) used as a measure of efficacy? $(+1 /+0)$

Other

Is the percentage of patients pain-free at $2 \mathrm{~h}$ used as a secondary measure of efficacy?

Is sustained pain-free (percentage of patients pain-free within $2 \mathrm{~h}$ with no use of rescue medication or relapse within $24 \mathrm{~h}$ ) used as a measure of efficacy?

Prophylaxis

\section{Selection of patients}

Do the diagnostic criteria conform to those of the IHS? $(+1 /+0)$

Do the patients' attacks of migraine occur 2-6 times per month? $(+1 /+0)$

Trial design

Is the trial double blind? $(+1 /+0)$

Is the trial placebo-controlled? $(+1 /+0)$

Were the trial participants randomized at entry to the trial? $(+1 /+0)$

Were the trial participants stratified for frequency of migraine attacks occurring during baseline? $(+1 /+0)$

Are treatment periods of at least 3 months used? $(+1 /+0)$

Evaluation of results

IHS recommended

Is frequency of migraine attacks per 4 weeks used as a primary measure of efficacy? $(+1 /+0)$

Is the number of days with migraine per 4 weeks used as a measure of efficacy? $(+1 /+0)$

Other

Is the number of days with headache per 4 weeks used as a measure of efficacy? "setting" (neurology, emergency medicine, internal medicine, general practice or other), location (US, Europe, other, multinational) and the diagnosis of patients treated in the trial.

For trials not using the recommended primary outcome measure the outcome measure actually used was registered.

For the prophylactic trials the following were also registered: whether the trial design was cross-over or parallelgroup, the duration of the treatment period and the attack frequency required for inclusion.

Acute trials could score a maximum of seven points, prophylactic trials a maximum of nine points, items.

To evaluate compliance with the IHS guidelines the following measures were defined a priori: mean score of randomized, double-blind (RDB) trials, mean score of all reviewed trials, percentage of trials either not randomized or not double-blind (non-RDB), percentage of RDB trials using the recommended primary efficacy measure, percentage of RDB trials that are placebo-controlled.

\section{Results}

\section{Data collection}

The search was performed on August 12, 2009. Searching Pubmed using HSSS retrieved 3,296 items. Searching CENTRAL retrieved 2,169 items and searching clinicaltrials.gov retrieved 233 items.

Of the 5,698 titles and abstracts screened 255 papers were retrieved in full. 12 papers were unretrievable. A total of 184 retrievable papers, containing reports on 145 acute [17-148] and 52 prophylactic trials [149-198], were considered eligible for further review.

\section{Evaluation of trials}

The IHS diagnostic criteria were used in by far the most studies (92\% of acute trials and $98 \%$ of prophylactic trials). The reports of studies that did not use IHS criteria did not mention the diagnostic criteria actually used, simply stated that a physician had diagnosed the patients or used modified IHS criteria (e.g. "at least three items from the list of criteria"[113]).

The median number of treated subjects in the acute trials was 328 (range 12-5,388) while the median number of treated subjects in the prophylactic trials was 88 (range $14-818$ ). $47 \%$ of acute trials and $37 \%$ of prophylactic trials were carried out in the US. $89 \%$ of both acute trials and prophylactic trials were carried out within a neurological setting.

Thirty-one percent of acute RDB trials applied the recommended "pain free at $2 \mathrm{~h}$ " as the primary efficacy 
Table 2 Results

\begin{tabular}{lcc}
\hline & Acute & Prophylaxis \\
\hline Mean score of RDB trials & 4.7 (range 2-6) & 5.6 (range 4-9) \\
Mean score of all reviewed trials & 4.4 (range 0-6) & 5.1 (range 1-9) \\
Percentage of non-RDB trials & $15.2 \%$ (22 of 145) & $9.6 \%$ (5 of 52) \\
Percentage of RDB trials using the & $30.9 \%$ (38 of 123) & $72.3 \%$ (34 of 47) \\
$\quad$ recommended primary efficacy measure & & \\
Percentage of RDB trials placebo-controlled & $82.9 \%$ (102 of 123) & $76.6 \%$ (36 of 47) \\
\hline
\end{tabular}

measure while $49 \%$ of acute RDB trials applied this measure as a secondary endpoint. "Headache relief" (a decrease from moderate or severe headache to none or mild) was the primary efficacy measure in $39 \%$ of the reviewed acute RDB trials. The "sustained pain free" endpoint was only used by $5(3 \%)$ acute trials. However, 68 (47\%) of acute trials used a modified and less rigorous version of this efficacy measure: the percentage of patients that sustained pain-free state at $24 \mathrm{~h}$ instead of the recommended $48 \mathrm{~h}$.

More than $86 \%$ of prophylactic trials used the recommended treatment duration of at least 3 months. The average treatment duration was 16.0 weeks. Only 3 (6\%) of the reviewed prophylactic trials applied stratification for migraine attack frequency. Seven of the prophylactic studies (14\%) used the recommended migraine attack frequency of 2-6 as an eligibility criterion. Most studies required an average attack frequency of different intervals between 3 and 12 attacks per month. Eight study reports did not mention an attack frequency requirement. $72 \%$ of the prophylactic studies used the recommended "migraine attacks per 4 weeks" as the primary efficacy measure.

\section{Discussion}

The IHS guidelines for drug trials in migraine consist of a series of recommendations with comments. Some recommendations in the guidelines are general for randomised clinical trials (RCTs), such as randomisation, doubleblinding and placebo-control. These recommendations are followed in $67 \%$ of the clinical studies. Other recommendations are migraine-specific, such as operational diagnostic criteria and primary efficacy measure. Amongst these recommendations the use of operational diagnostic criteria is a major contributor to the external validity of the results of the RCT. The IHS diagnostic criteria were used in $94 \%$ of the RCTs Fig. 1, 2.

The choice of a primary efficacy measure is crucial when designing a drug trial. It is also important that the same primary efficacy is used in similar RCTs when metaanalyses are performed. Some consensus internationally is therefore needed and international guidelines like these of IHS are suggested in order to provide this consensus. In the first IHS guidelines 'complete response' [13], which

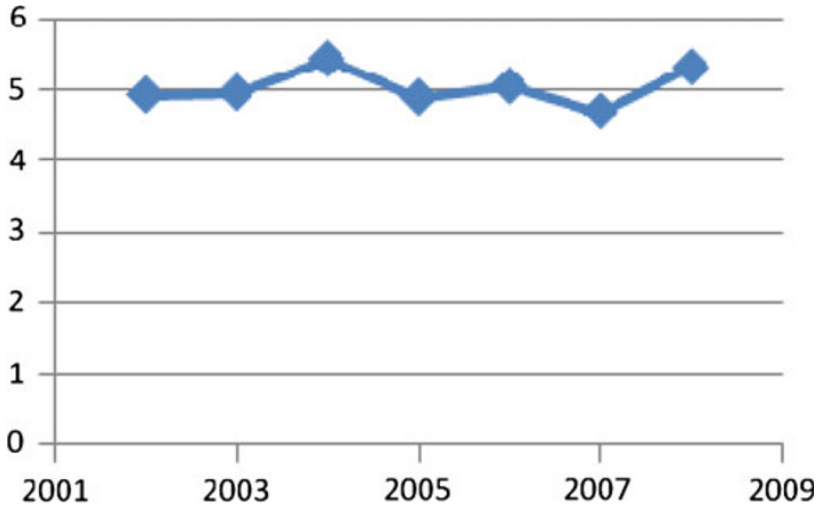

Fig. 1 Average scores for acute trials

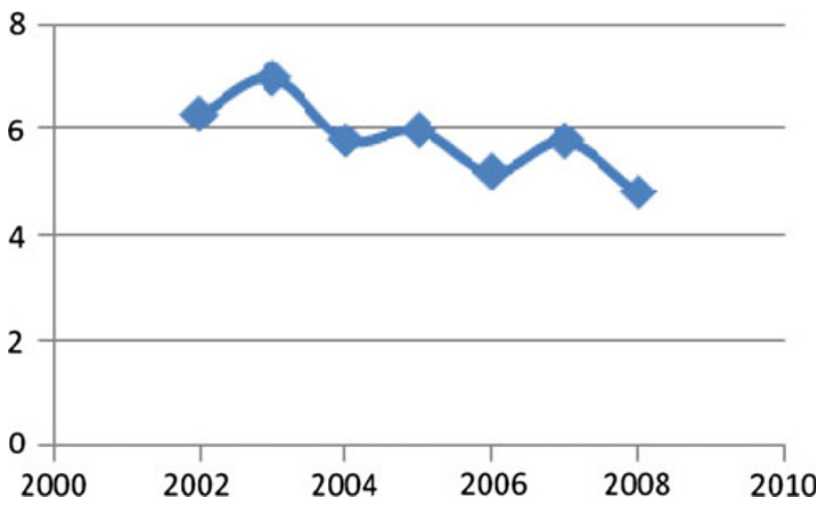

Fig. 2 Average scores for prophylactic trials

was very similar to current "sustained pain-free" [14] was suggested as the primary efficacy measure. At the same time Glaxo used, in the extensive trial programme of sumatriptan, its so-called "Glaxo criterion": a decrease in headache from severe or moderate to none or mild [199]. This 'headache relief' was subsequently used in the extensive trial programs of the triptans, naratriptan, zolmitriptan, rizatriptan, almotriptan, eletriptan and frovatriptan in the 1990s [1] and its use persisted into the 2010s [200]. In 2000, pain-free after $2 \mathrm{~h}$ was recommended as the primary efficacy parameter by IHS. Only $31 \%$ of the RCTs of acute treatment reviewed here comply with this recommendation. However, this endpoint has been used in an increasing number of RCTs (Fig. 3). 


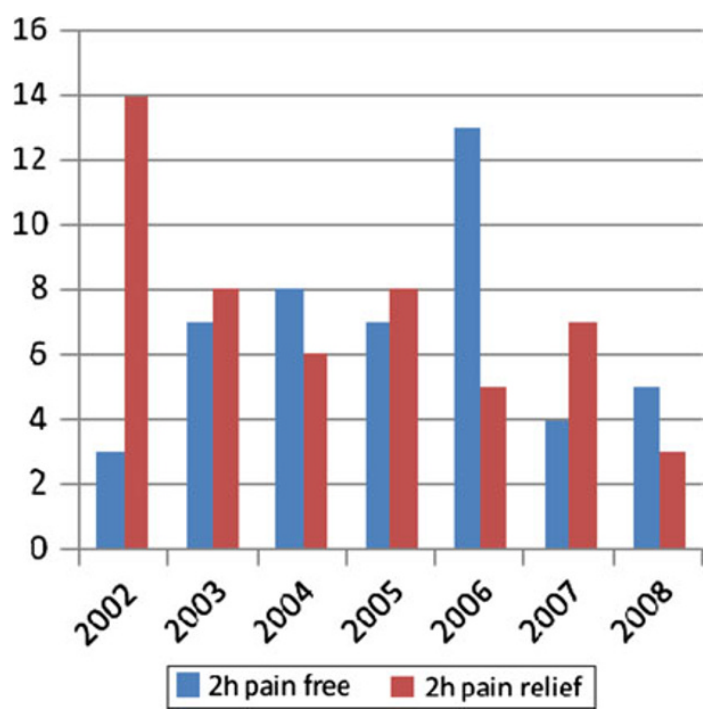

Fig. 3 Number of trials using "2 h pain free" and " 2 h pain relief", respectively, as a primary efficacy endpoint

Studies of patient satisfaction have consistently shown that patients consider complete relief of pain, a fast onset of action and no pain recurrence the most desirable effects of a migraine drug for acute treatment [201, 202]. While the "headache relief" endpoint is an effective measurement of patients' response to treatment it, thus, does not reflect what patients actually consider important. Furthermore, "headache relief" has a much higher placebo rate than "pain free" [203].

Some of the acute trials apply even more rigorous primary efficacy endpoints, such as "pain free at $30 \mathrm{~min}$ " [82] or "total symptom relief at $1 \mathrm{~h}$ " [59]. Nearly $50 \%$ of the acute trials use the composite endpoint of "sustained pain free" either for 24 or $48 \mathrm{~h}$. "Sustained pain free" is probably the ideal drug response in regard to patients' requests. It is obtained, however, in only $20-30 \%$ of triptan trials [3].

A few of the acute trials do not have the treatment of headache as their primary objective. These trials focus on the accompanying symptoms of nausea, photophobia and phonophobia. This is acceptable and clinically relevant since some migraineurs consider these symptoms to be the main problem.

Several of the acute trials investigate the relationship between the timing of drug intake (in relation to the onset of migraine pain or cutaneous allodynia) and drug efficacy $[23,62,73,86,102,103,122,130]$. The results of these trials suggest that "early" triptan administration, while the headache is mild, is more efficient in terms of pain-free outcomes and reduced risk of recurrence when compared to "late" administration, when the headache is moderate to severe.
In acute trials of migraine with aura exclusively, drugs could be taken either during the aura phase or during the headache phase [11]. An efficacy endpoint in such a trial could very well be the duration of the aura, since many patients suffering from migraine with aura are severely disabled by the aura itself. Alternatively, the efficacy measure could be whether the migraine headache occurs. Some of these patients often or even exclusively have a mild tension-type like headache following their aura [7]. These patients obviously regard their aura symptoms and not their headache as the main problem.

The prophylactic trials comply well with using the recommended primary efficacy measure. There are currently no studies of what effects patients specifically request from preventive treatment. Possibilities could be lowering of attack frequency, shortening of attack duration, amelioration of migraine intensity or less days of absence from work. A recent study showed that patients generally prefer treatments highly efficient in reducing attack frequency over treatments causing few side-effects and requiring infrequent dosing [204].

Stratification for frequency of migraine attacks is only used by three of the reviewed prophylactic studies and none of these make use of the baseline stratification in the following statistical analyses. This is probably because attack frequency per se is not thought of as an important prognostic factor for treatment response. This is unfortunate as this has previously been shown to be the case [205] and the knowledge that could be obtained by stratification could be clinically useful and serve as a basis for further studies.

The recommended attack frequency requirement of 2-6 attacks per month for preventive trials has not gained popularity. It should be noted that this requirement is not feasible for some studies of the migraine subtypes which is obvious for chronic migraine and for menstrually related migraine (MRM).

Specific guidelines for trials in chronic migraine have recently been published in 2009 by the IHS [206] in which the recommended primary endpoint depends on the study objective but includes the number of headache days, the number of migraine days or the number of migraine episodes. The four trials reviewed here adhere to this recommendation. Recommendations for trials in MRM specifically are contained in the second edition of the IHS guidelines.

Nearly $14 \%$ of the reviewed trials are either not randomized or not double-blind. These studies are especially prevalent amongst the acute trials. Open-label studies in general are often smaller, explorative early phase studies. For the non-RDB acute trials reviewed here, however, the average number of treated patients is 556, i.e. larger than the overall average of the acute trials. Three huge studies of 
more than 2,300 subjects each contribute to this average $[18,53,72]$. One of these trials scored a total of 0 on the rating scale used in this review. Randomization and the double-blind technique are generally considered to be the cornerstones of quality trials. Because of the above-mentioned subjective nature and large placebo effect, this especially holds true for migraine studies. In addition these features are fairly cheap and easy to apply. In some special cases it is not possible to effectively blind the investigator (e.g. surgical procedures) or the patients (e.g. trials of drugs with characteristic and commonly known side-effects). If this is not the case, performing open-label or non-randomized trials in migraine can hardly be considered anything but unethical to both the patients treated and to the rest of the scientific society.

Investigators should be careful when reporting the details of their studies and avoid using ambiguous or implicit terms or methods. For example, in this study it was found that several studies did not specify that the diagnosis of migraine was made based on the IHS criteria even though this was highly possible as the investigators had used these criteria in all of their previous studies. In some trials the word "headache" is used synonymously with migraine headache even though "headache" of course could refer to all other kinds of head pain. Thus, there is an important difference between having "reduction of migraine days" or "reduction of headache days" as an efficacy endpoint, especially since migraineurs often experience tension-type headache between migraine attacks ("interval headache") [207]. Many prophylactic trials do not specify the attack frequency required for eligibility even though this is highly relevant. Most prophylactic trials also neglect the important aspect of defining how long a time span between attacks is required for the attacks to be regarded as separate and not a case of recurrence.

This study is limited by its use of a very simplified version of the IHS guidelines for assessing adherence. Other elements of the guidelines could have been assessed as well. Result accuracy could have been increased by employing multiple reviewers. The reports reviewed were published between 2002 and 2008. Some study protocols have necessarily been written before the publication of the 2000 IHS guidelines. One study published in 2006 [145] was actually done in 1988 , i.e. before the publication of the first edition of the IHS guidelines.

In conclusion, even though the quality of clinical trials in migraine is generally high and the IHS recommendations are well adhered to, there is still room for improvement. Investigators should be encouraged to report meticulously and to use clinically relevant primary efficacy measures. The once popular "headache response" endpoint for acute trials should now be considered obsolete. Stratification should be applied in future parallel-group prophylactic trials.

Open-label or non-randomized trials generally have no place in the study of migraine drugs.

The IHS should develop specific guidelines for assessment of effects of the timing of drug administration in acute trials, e.g. by providing definitions of the terms "early migraine" and "mild migraine" as well as other relevant phenomena such as cutaneous allodynia.

Furthermore, the IHS should offer specific guidelines for migraine subtypes such as migraine with aura [208] and for special treatments such as botulinum toxin injections and similar complex regimens that could be seen in future migraine trials.

Conflict of interest None.

\section{References}

1. Tfelt-Hansen P, De Vries P, Saxena PR (2000) Triptans in migraine: a comparative review of pharmacology, pharmacokinetics and efficacy. Drugs 60:1259-1287

2. Lampl C, Voelker M, Diener HC (2007) Efficacy and safety of $1,000 \mathrm{mg}$ effervescent aspirin: individual patient data metaanalysis of three trials in migraine headache and migraine accompanying symptoms. J Neurol 254:705-712

3. Ferrari MD, Roon KI, Lipton RB, Goadsby PJ (2001) Oral triptans (serotonin 5-HT(1B/1D) agonists) in acute migraine treatment: a meta-analysis of 53 trials. Lancet 358:1668-1675

4. Mett A, Tfelt-Hansen P (2008) Acute migraine therapy: recent evidence from randomized comparative trials. Curr.Opin.Neurol 21:331-337

5. Tfelt-Hansen P, Steiner TJ (2007) Over-the-counter triptans for migraine : what are the implications? CNS Drugs 21:877-883

6. Lyngberg AC, Rasmussen BK, Jorgensen T, Jensen R (2005) Secular changes in health care utilization and work absence for migraine and tension-type headache: a population based study. Eur J Epidemiol 20:1007-1014

7. Olesen J, Goadsby PJ, Ramadan NM, Tfelt-Hansen P, Welch KM (2006) The headaches, 3rd edn. Lippincott Williams \& Wilkins, Philadelphia

8. Villalon CM, Olesen J (2009) The role of CGRP in the pathophysiology of migraine and efficacy of CGRP receptor antagonists as acute antimigraine drugs. Pharmacol Ther 124:309-323

9. Lassen LH, Ashina M, Christiansen I, Ulrich V, Olesen J (1997) Nitric oxide synthase inhibition in migraine. Lancet 349:401-402

10. Goadsby PJ, Ferrari MD, Csanyi A, Olesen J, Mills JG (2009) Randomized, double-blind, placebo-controlled, proof-of-concept study of the cortical spreading depression inhibiting agent tonabersat in migraine prophylaxis. Cephalalgia 29:742-750

11. Hauge AW, Asghar MS, Schytz HW, Christensen K, Olesen J (2009) Effects of tonabersat on migraine with aura: a randomised, double-blind, placebo-controlled crossover study. Lancet Neurol 8:718-723

12. Tfelt-Hansen PC (2009) Unpublished clinical trials with sumatriptan. Lancet 374:1501-1502

13. (1991) Guidelines for controlled trials of drugs in migraine. First edition. International Headache Society Committee on Clinical Trials in Migraine. Cephalalgia 11:1-12 
14. Tfelt-Hansen P, Block G, Dahlof C, Diener HC, Ferrari MD, Goadsby PJ, Guidetti V, Jones B, Lipton RB, Massiou H, Meinert C, Sandrini G, Steiner T, Winter PB (2000) Guidelines for controlled trials of drugs in migraine: second edition. Cephalalgia 20:765-786

15. European Medicines Agency (2007) Guideline on Clinical Investigation of Medicinal Products for the Treatment of Migraine. European Medicines Agency, London

16. The Cochrane Collaboration (2009) The Cochrane Handbook for Systematic Reviews of Interventions. Version 5.0.2. The Cochrane Collaboration, Oxford

17. Alemdar M, Pekdemir M, Selekler HM (2007) Single-dose intravenous tramadol for acute migraine pain in adults: a singleblind, prospective, randomized, placebo-controlled clinical trial. Clin Ther 29:1441-1447

18. Bell CF, Foley KA, Barlas S, Solomon G, Hu XH (2006) Time to pain freedom and onset of pain relief with rizatriptan $10 \mathrm{mg}$ and prescription usual-care oral medications in the acute treatment of migraine headaches: a multicenter, prospective, openlabel, two-attack, crossover study. Clin Ther 28:872-880

19. Bigal M, Sheftell F, Tepper S, Tepper D, Ho TW, Rapoport A (2008) A randomized double-blind study comparing rizatriptan, dexamethasone, and the combination of both in the acute treatment of menstrually related migraine. Headache 48:12861293

20. Bigal ME, Bordini CA, Speciali JG (2002) Intravenous chlorpromazine in the emergency department treatment of migraines: a randomized controlled trial. J Emerg Med 23:141-148

21. Bigal ME, Bordini CA, Tepper SJ, Speciali JG (2002) Intravenous dipyrone in the acute treatment of migraine without aura and migraine with aura: a randomized, double blind, placebocontrolled study. Headache 42:862-871

22. Bigal ME, Bordini CA, Tepper SJ, Speciali JG (2002) Intravenous magnesium sulphate in the acute treatment of migraine without aura and migraine with aura. A randomized, doubleblind, placebo-controlled study. Cephalalgia 22:345-353

23. Brandes JL, Kudrow D, Cady R, Tiseo PJ, Sun W, Sikes CR (2005) Eletriptan in the early treatment of acute migraine: influence of pain intensity and time of dosing. Cephalalgia 25:735-742

24. Brandes JL, Kudrow D, Stark SR, O'Carroll CP, Adelman JU, O'Donnell FJ, Alexander WJ, Spruill SE, Barrett PS, Lener SE (2007) Sumatriptan-naproxen for acute treatment of migraine: a randomized trial. JAMA 297:1443-1454

25. Cady R, Elkind A, Goldstein J, Keywood C (2004) Randomized, placebo-controlled comparison of early use of frovatriptan in a migraine attack versus dosing after the headache has become moderate or severe. Curr Med Res Opin 20:1465-1472

26. Cady R, Martin V, Mauskop A, Rodgers A, Hustad CM, Ramsey KE, Skobieranda F (2006) Efficacy of rizatriptan $10 \mathrm{mg}$ administered early in a migraine attack. Headache 46:914-924

27. Carpay J, Schoenen J, Ahmad F, Kinrade F, Boswell D (2004) Efficacy and tolerability of sumatriptan tablets in a fast-disintegrating, rapid-release formulation for the acute treatment of migraine: results of a multicenter, randomized, placebo-controlled study. Clin Ther 26:214-223

28. Cete Y, Dora B, Ertan C, Ozdemir C, Oktay C (2005) A randomized prospective placebo-controlled study of intravenous magnesium sulphate versus metoclopramide in the management of acute migraine attacks in the Emergency Department. Cephalalgia 25:199-204

29. Charlesworth BR, Dowson AJ, Purdy A, Becker WJ, BoesHansen S, Farkkila M (2003) Speed of onset and efficacy of zolmitriptan nasal spray in the acute treatment of migraine: a randomised, double-blind, placebo-controlled, dose-ranging study versus zolmitriptan tablet. CNS Drugs 17:653-667
30. Christie S, Gobel H, Mateos V, Allen C, Vrijens F, Shivaprakash M (2003) Crossover comparison of efficacy and preference for rizatriptan $10 \mathrm{mg}$ versus ergotamine/caffeine in migraine. Eur Neurol 49:20-29

31. Di Monda V, Nicolodi M, Aloisio A, Del Bianco P, Fonzari M, Grazioli I, Uslenghi C, Vecchiet L, Sicuteri F (2003) Efficacy of a fixed combination of indomethacin, prochlorperazine, and caffeine versus sumatriptan in acute treatment of multiple migraine attacks: a multicenter, randomized, crossover trial. Headache 43:835-844

32. Dib M, Massiou H, Weber M, Henry P, Garcia-Acosta S, Bousser MG (2002) Efficacy of oral ketoprofen in acute migraine: a double-blind randomized clinical trial. Neurology 58:1660-1665

33. Diener HC, Jansen JP, Reches A, Pascual J, Pitei D, Steiner TJ (2002) Efficacy, tolerability and safety of oral eletriptan and ergotamine plus caffeine (Cafergot) in the acute treatment of migraine: a multicentre, randomised, double-blind, placebocontrolled comparison. Eur Neurol 47:99-107

34. Diener HC (2003) RPR100893, a substance-P antagonist, is not effective in the treatment of migraine attacks. Cephalalgia 23:183-185

35. Diener HC, Bussone G, de Liano H, Eikermann A, Englert R, Floeter T, Gallai V, Gobel H, Hartung E, Jimenez MD, Lange R, Manzoni GC, Mueller-Schwefe G, Nappi G, Pinessi L, Prat J, Puca FM, Titus F, Voelker M (2004) Placebo-controlled comparison of effervescent acetylsalicylic acid, sumatriptan and ibuprofen in the treatment of migraine attacks. Cephalalgia 24:947-954

36. Diener HC, Eikermann A, Gessner U, Gobel H, Haag G, Lange R, May A, Muller-Schwefe G, Voelker M (2004) Efficacy of 1, $000 \mathrm{mg}$ effervescent acetylsalicylic acid and sumatriptan in treating associated migraine symptoms. Eur Neurol 52:50-56

37. Diener HC (2005) Efficacy of almotriptan $12.5 \mathrm{mg}$ in achieving migraine-related composite endpoints: a double-blind, randomized, placebo-controlled study in patients controlled study in patients with previous poor response to sumatriptan $50 \mathrm{mg}$. Curr Med Res Opin 21:1603-1610

38. Diener HC, Gendolla A, Gebert I, Beneke M (2005) Almotriptan in migraine patients who respond poorly to oral sumatriptan: a double-blind, randomized trial. Headache 45:874-882

39. Diener HC, Montagna P, Gacs G, Lyczak P, Schumann G, Zoller B, Mulder LJ, Siegel J, Edson K (2006) Efficacy and tolerability of diclofenac potassium sachets in migraine: a randomized, double-blind, cross-over study in comparison with diclofenac potassium tablets and placebo. Cephalalgia 26:537-547

40. Diez FI, Straube A, Zanchin G (2007) Patient preference in migraine therapy. A randomized, open-label, crossover clinical trial of acute treatment of migraine with oral almotriptan and rizatriptan. J Neurol 254:242-249

41. Dodick D, Brandes J, Elkind A, Mathew N, Rodichok L (2005) Speed of onset, efficacy and tolerability of zolmitriptan nasal spray in the acute treatment of migraine: a randomised, doubleblind, placebo-controlled study. CNS Drugs 19:125-136

42. Dodick DW (2002) Almotriptan increases sustained pain-free outcomes in acute migraine: results from three controlled clinical trials. Headache 42:21-27

43. Dowson AJ, Massiou H, Lainez JM, Cabarrocas X (2002) Almotriptan is an effective and well-tolerated treatment for migraine pain: results of a randomized, double-blind, placebocontrolled clinical trial. Cephalalgia 22:453-461

44. Dowson AJ, MacGregor EA, Purdy RA, Becker WJ, Green J, Levy SL (2002) Zolmitriptan orally disintegrating tablet is effective in the acute treatment of migraine. Cephalalgia 22:101-106 
45. Dowson AJ, Charlesworth BR, Purdy A, Becker WJ, BoesHansen S, Farkkila M (2003) Tolerability and consistency of effect of zolmitriptan nasal spray in a long-term migraine treatment trial. CNS Drugs 17:839-851

46. Dowson AJ, Massiou H, Aurora SK (2005) Managing migraine headaches experienced by patients who self-report with menstrually related migraine: a prospective, placebo-controlled study with oral sumatriptan. J Headache Pain 6:81-87

47. Eletriptan Steering Committee in Japan (2002) Efficacy and safety of eletriptan $20 \mathrm{mg}, 40 \mathrm{mg}$ and $80 \mathrm{mg}$ in Japanese migraineurs. Cephalalgia 22:416-423

48. Engindeniz Z, Demircan C, Karli N, Armagan E, Bulut M, Aydin T, Zarifoglu M (2005) Intramuscular tramadol versus diclofenac sodium for the treatment of acute migraine attacks in emergency department: a prospective, randomised, double-blind study. J Headache Pain 6:143-148

49. Farkkila M, Olesen J, Dahlof C, Stovner LJ, ter Bruggen JP, Rasmussen S, Muirhead N, Sikes C (2003) Eletriptan for the treatment of migraine in patients with previous poor response or tolerance to oral sumatriptan. Cephalalgia 23:463-471

50. Freitag F, Diamond M, Diamond S, Janssen I, Rodgers A, Skobieranda F (2008) Efficacy and tolerability of coadministration of rizatriptan and acetaminophen versus rizatriptan or acetaminophen alone for acute migraine treatment. Headache 48:921-930

51. Freitag F, Taylor FR, Hamid MA, Rodgers A, Hustad CM, Ramsey KE, Skobieranda F (2008) Elimination of migraineassociated nausea in patients treated with rizatriptan orally disintegrating tablet (ODT): a randomized, double-blind, placebocontrolled study. Headache 48:368-377

52. Freitag F, Smith T, Mathew N, Rupnow M, Greenberg S, Mao L, Finlayson G, Wright P, Biondi D (2008) Effect of early intervention with almotriptan versus placebo on migraine-associated functional disability: results from the AEGIS Trial. Headache 48:341-354

53. Freitag FG, Finlayson G, Rapoport AM, Elkind AH, Diamond ML, Unger JR, Fisher AC, Armstrong RB, Hulihan JF, Greenberg SJ (2007) Effect of pain intensity and time to administration on responsiveness to almotriptan: results from AXERT $12.5 \mathrm{mg}$ Time Versus Intensity Migraine Study (AIMS). Headache 47:519-530

54. Friedman BW, Corbo J, Lipton RB, Bijur PE, Esses D, Solorzano C, Gallagher EJ (2005) A trial of metoclopramide versus sumatriptan for the emergency department treatment of migraines. Neurology 64:463-468

55. Friedman BW, Hochberg M, Esses D, Bijur PE, Corbo J, Paternoster J, Solorzano C, Toosi B, Lipton RB, Gallagher EJ (2006) A clinical trial of trimethobenzamide/diphenhydramine versus sumatriptan for acute migraines. Headache 46:934941

56. Friedman BW, Greenwald P, Bania TC, Esses D, Hochberg M, Solorzano C, Corbo J, Chu J, Chew E, Cheung P, Fearon S, Paternoster J, Baccellieri A, Clark S, Bijur PE, Lipton RB, Gallagher EJ (2007) Randomized trial of IV dexamethasone for acute migraine in the emergency department. Neurology 69:2038-2044

57. Friedman BW, Esses D, Solorzano C, Dua N, Greenwald P, Radulescu R, Chang E, Hochberg M, Campbell C, Aghera A, Valentin T, Paternoster J, Bijur P, Lipton RB, Gallagher EJ (2008) A randomized controlled trial of prochlorperazine versus metoclopramide for treatment of acute migraine. Ann Emerg Med 52:399-406

58. Garcia-Ramos G, MacGregor EA, Hilliard B, Bordini CA, Leston J, Hettiarachchi J (2003) Comparative efficacy of eletriptan versus naratriptan in the acute treatment of migraine. Cephalalgia 23:869-876
59. Gawel M, Aschoff J, May A, Charlesworth BR (2005) Zolmitriptan $5 \mathrm{mg}$ nasal spray: efficacy and onset of action in the acute treatment of migraine-results from phase 1 of the REALIZE Study. Headache 45:7-16

60. Geraud G, Compagnon A, Rossi A (2002) Zolmitriptan versus a combination of acetylsalicylic acid and metoclopramide in the acute oral treatment of migraine: a double-blind, randomised, three-attack study. Eur Neurol 47:88-98

61. Goadsby PJ, Massiou H, Pascual J, Diener HC, Dahlof CG, Mateos V, Dowson AJ, Raets I, Cunha L, Farkkila M, Manzoni GC (2007) Almotriptan and zolmitriptan in the acute treatment of migraine. Acta Neurol Scand 115:34-40

62. Goadsby PJ, Zanchin G, Geraud G, De Klippel N, Diaz-Insa S, Gobel H, Cunha L, Ivanoff N, Falques M, Fortea J (2008) Early versus non-early intervention in acute migraine-'Act when Mild (AwM)'. A double-blind, placebo-controlled trial of almotriptan. Cephalalgia 28:383-391

63. Gobel H, Heinze A, Niederberger U, Witt T, Zumbroich V (2004) Efficacy of phenazone in the treatment of acute migraine attacks: a double-blind, placebo-controlled, randomized study. Cephalalgia 24:888-893

64. Goldstein J, Keywood C (2002) Frovatriptan for the acute treatment of migraine: a dose-finding study. Headache 42:41-48

65. Goldstein J, Silberstein SD, Saper JR, Elkind AH, Smith TR, Gallagher RM, Battikha JP, Hoffman H, Baggish J (2005) Acetaminophen, aspirin, and caffeine versus sumatriptan succinate in the early treatment of migraine: results from the ASSET trial. Headache 45:973-982

66. Goldstein J, Silberstein SD, Saper JR, Ryan RE Jr, Lipton RB (2006) Acetaminophen, aspirin, and caffeine in combination versus ibuprofen for acute migraine: results from a multicenter, double-blind, randomized, parallel-group, single-dose, placebocontrolled study. Headache 46:444-453

67. Ho TW, Ferrari MD, Dodick DW, Galet V, Kost J, Fan X, Leibensperger H, Froman S, Assaid C, Lines C, Koppen H, Winner PK (2008) Efficacy and tolerability of MK-0974 (telcagepant), a new oral antagonist of calcitonin gene-related peptide receptor, compared with zolmitriptan for acute migraine: a randomised, placebo-controlled, parallel-treatment trial. Lancet 372:2115-2123

68. Ho TW, Mannix LK, Fan X, Assaid C, Furtek C, Jones CJ, Lines CR, Rapoport AM (2008) Randomized controlled trial of an oral CGRP receptor antagonist, MK-0974, in acute treatment of migraine. Neurology 70:1304-1312

69. Honkaniemi J, Liimatainen S, Rainesalo S, Sulavuori S (2006) Haloperidol in the acute treatment of migraine: a randomized, double-blind, placebo-controlled study. Headache 46:781-787

70. Ishkanian G, Blumenthal H, Webster CJ, Richardson MS, Ames M (2007) Efficacy of sumatriptan tablets in migraineurs selfdescribed or physician-diagnosed as having sinus headache: a randomized, double-blind, placebo-controlled study. Clin Ther 29:99-109

71. Jakubowski M, Levy D, Goor-Aryeh I, Collins B, Bajwa Z, Burstein R (2005) Terminating migraine with allodynia and ongoing central sensitization using parenteral administration of COX1/COX2 inhibitors. Headache 45:850-861

72. Jamieson D, Cutrer FM, Goldstein J, Dayno J, Hu XH (2003) Real-world experiences in migraine therapy with rizatriptan. Headache 43:223-230

73. Jelinski SE, Becker WJ, Christie SN, Ahmad FE, Pryse-Phillips W, Simpson SD (2006) Pain free efficacy of sumatriptan in the early treatment of migraine. Can J Neurol Sci 33:73-79

74. Kaniecki R, Ruoff G, Smith T, Barrett PS, Ames MH, Byrd S, Kori S (2006) Prevalence of migraine and response to sumatriptan in patients self-reporting tension/stress headache. Curr Med Res Opin 22:1535-1544 
75. Kelly AM, Kerr D, Clooney M (2008) Impact of oral dexamethasone versus placebo after ED treatment of migraine with phenothiazines on the rate of recurrent headache: a randomised controlled trial. Emerg Med J 25:26-29

76. Klapper J, Lucas C, Rosjo O, Charlesworth B (2004) Benefits of treating highly disabled migraine patients with zolmitriptan while pain is mild. Cephalalgia 24:918-924

77. Kolodny A, Polis A, Battisti WP, Johnson-Pratt L, Skobieranda F (2004) Comparison of rizatriptan $5 \mathrm{mg}$ and $10 \mathrm{mg}$ tablets and sumatriptan $25 \mathrm{mg}$ and $50 \mathrm{mg}$ tablets. Cephalalgia 24:540-546

78. Krymchantowski AV, Barbosa JS (2002) Rizatriptan combined with rofecoxib versus rizatriptan for the acute treatment of migraine: an open label pilot study. Cephalalgia 22:309-312

79. Krymchantowski AV, Bigal ME (2004) Rizatriptan versus rizatriptan plus rofecoxib versus rizatriptan plus tolfenamic acid in the acute treatment of migraine. BMC Neurol 4:10

80. Krymchantowski AV, Peixoto P, Higashi R, Silva A Jr, Schutz V (2005) Lysine clonixinate vs naproxen sodium for the acute treatment of migraine: a double-blind, randomized, crossover study. Med Gen Med 7:69

81. Krymchantowski AV, Filho PF, Bigal ME (2006) Rizatriptan versus rizatriptan plus trimebutine for the acute treatment of migraine: a double-blind, randomized, cross-over, placebocontrolled study. Cephalalgia 26:871-874

82. Krymchantowski AV, Carneiro H, Barbosa J, Jevoux C (2008) Lysine clonixinate versus dipyrone (metamizole) for the acute treatment of severe migraine attacks: a single-blind, randomized study. Arq Neuropsiquiatr 66:216-220

83. Kudrow D, Thomas HM, Ruoff G, Ishkanian G, Sands G, Le VH, Brown MT (2005) Valdecoxib for treatment of a single, acute, moderate to severe migraine headache. Headache 45:1151-1162

84. Lainez MJ, Evers S, Kinge E, Allais G, Allen C, Rao NA, Massaad R, Lis K (2006) Preference for rizatriptan 10-mg wafer versus eletriptan $40-\mathrm{mg}$ tablet for acute treatment of migraine. Cephalalgia 26:246-256

85. Lainez MJ, Galvan J, Heras J, Vila C (2007) Crossover, doubleblind clinical trial comparing almotriptan and ergotamine plus caffeine for acute migraine therapy. Eur J Neurol 14:269-275

86. Lampl C, Huber G, Haas S, Rittberger E, Diener HC (2008) Difference in triptan effect in patients with migraine and early allodynia. Cephalalgia 28:1031-1038

87. Landy S, Savani N, Shackelford S, Loftus J, Jones M (2004) Efficacy and tolerability of sumatriptan tablets administered during the mild-pain phase of menstrually associated migraine. Int J Clin Pract 58:913-919

88. Landy SH, McGinnis JE, McDonald SA (2005) Pilot study evaluating preference for 3-mg versus 6-mg subcutaneous sumatriptan. Headache 45:346-349

89. Leinisch E, Evers S, Kaempfe N, Kraemer C, Sostak P, Jurgens T, Straube A, May A (2005) Evaluation of the efficacy of intravenous acetaminophen in the treatment of acute migraine attacks: a double-blind, placebo-controlled parallel group multicenter study. Pain 117:396-400

90. Leniger T, Pageler L, Stude P, Diener HC, Limmroth V (2005) Comparison of intravenous valproate with intravenous lysineacetylsalicylic acid in acute migraine attacks. Headache 45:4246

91. Levy MJ, Matharu MS, Bhola R, Meeran K, Goadsby PJ (2005) Octreotide is not effective in the acute treatment of migraine. Cephalalgia 25:48-55

92. Linde M, Mellberg A, Dahlof C (2006) Subcutaneous sumatriptan provides symptomatic relief at any pain intensity or time during the migraine attack. Cephalalgia 26:113-121

93. Linder SL, Mathew NT, Cady RK, Finlayson G, Ishkanian G, Lewis DW (2008) Efficacy and tolerability of almotriptan in adolescents: a randomized, double-blind, placebo-controlled trial. Headache 48:1326-1336

94. Lipton RB, Goldstein J, Baggish JS, Yataco AR, Sorrentino JV, Quiring JN (2005) Aspirin is efficacious for the treatment of acute migraine. Headache 45:283-292

95. Loder E, Silberstein SD, Abu-Shakra S, Mueller L, Smith T (2004) Efficacy and tolerability of oral zolmitriptan in menstrually associated migraine: a randomized, prospective, parallel-group, double-blind, placebo-controlled study. Headache 44:120-130

96. Loder E, Freitag FG, Adelman J, Pearlmand S, Abu-Shakra S (2005) Pain-free rates with zolmitriptan $2.5 \mathrm{mg}$ ODT in the acute treatment of migraine: results of a large double-blind placebo-controlled trial. Curr Med Res Opin 21:381-389

97. Loo CY, Tan HJ, Teh HS, Raymond AA (2007) Randomised, open label, controlled trial of celecoxib in the treatment of acute migraine. Singapore Med J 48:834-839

98. MacGregor EA, Dowson A, Davies PT (2002) Mouth-dispersible aspirin in the treatment of migraine: a placebo-controlled study. Headache 42:249-255

99. Mannix LK, Loder E, Nett R, Mueller L, Rodgers A, Hustad CM, Ramsey KE, Skobieranda F (2007) Rizatriptan for the acute treatment of ICHD-II proposed menstrual migraine: two prospective, randomized, placebo-controlled, double-blind studies. Cephalalgia 27:414-421

100. Massiou H, Jamin C, Hinzelin G, Bidaut-Mazel C (2005) Efficacy of oral naratriptan in the treatment of menstrually related migraine. Eur J Neurol 12:774-781

101. Mathew NT, Schoenen J, Winner P, Muirhead N, Sikes CR (2003) Comparative efficacy of eletriptan $40 \mathrm{mg}$ versus sumatriptan $100 \mathrm{mg}$. Headache 43:214-222

102. Mathew NT, Kailasam J, Meadors L (2004) Early treatment of migraine with rizatriptan: a placebo-controlled study. Headache 44:669-673

103. Mathew NT, Finlayson G, Smith TR, Cady RK, Adelman J, Mao L, Wright P, Greenberg SJ (2007) Early intervention with almotriptan: results of the AEGIS trial (AXERT Early Migraine Intervention Study). Headache 47:189-198

104. Meredith JT, Wait S, Brewer KL (2003) A prospective doubleblind study of nasal sumatriptan versus IV ketorolac in migraine. Am J Emerg Med 21:173-175

105. Misra UK, Jose M, Kalita J (2004) Rofecoxib versus ibuprofen for acute treatment of migraine: a randomised placebo controlled trial. Postgrad Med J 80:720-723

106. Misra UK, Kalita J, Yadav RK (2007) Rizatriptan vs. ibuprofen in migraine: a randomised placebo-controlled trial. J Headache Pain 8:175-179

107. Nett R, Landy S, Shackelford S, Richardson MS, Ames M, Lener M (2003) Pain-free efficacy after treatment with sumatriptan in the mild pain phase of menstrually associated migraine. Obstet Gynecol 102:835-842

108. Olesen J, Diener HC, Schoenen J, Hettiarachchi J (2004) No effect of eletriptan administration during the aura phase of migraine. Eur J Neurol 11:671-677

109. Olesen J, Diener HC, Husstedt IW, Goadsby PJ, Hall D, Meier U, Pollentier S, Lesko LM (2004) Calcitonin gene-related peptide receptor antagonist BIBN 4096 BS for the acute treatment of migraine. N Engl J Med 350:1104-1110

110. Peroutka SJ, Lyon JA, Swarbrick J, Lipton RB, Kolodner K, Goldstein J (2004) Efficacy of diclofenac sodium softgel $100 \mathrm{mg}$ with or without caffeine $100 \mathrm{mg}$ in migraine without aura: a randomized, double-blind, crossover study. Headache 44:136-141

111. Rapoport A, Ryan R, Goldstein J, Keywood C (2002) Dose range-finding studies with frovatriptan in the acute treatment of migraine. Headache 42(Suppl 2):S74-S83 
112. Richman PB, Allegra J, Eskin B, Doran J, Reischel U, Kaiafas C, Nashed AH (2002) A randomized clinical trial to assess the efficacy of intramuscular droperidol for the treatment of acute migraine headache. Am J Emerg Med 20:39-42

113. Rowe BH, Colman I, Edmonds ML, Blitz S, Walker A, Wiens S (2008) Randomized controlled trial of intravenous dexamethasone to prevent relapse in acute migraine headache. Headache 48:333-340

114. Ryan R, Geraud G, Goldstein J, Cady R, Keywood C (2002) Clinical efficacy of frovatriptan: placebo-controlled studies. Headache 42(Suppl 2):S84-S92

115. Sakai F, Iwata M, Tashiro K, Itoyama Y, Tsuji S, Fukuuchi Y, Sobue G, Nakashima K, Morimatsu M (2002) Zolmitriptan is effective and well tolerated in Japanese patients with migraine: a dose-response study. Cephalalgia 22:376-383

116. Sandrini G, Farkkila M, Burgess G, Forster E, Haughie S (2002) Eletriptan versus sumatriptan: a double-blind, placebo-controlled, multiple migraine attack study. Neurology 59:1210-1217

117. Sandrini G, Cerbo R, Del Bene E, Ferrari A, Genco S, Grazioli I, Martelletti P, Nappi G, Pinessi L, Sarchielli P, Tamburro P, Uslenghi C, Zanchin G (2007) Efficacy of double-blind, doubledummy, randomised, parallel group, multicentre study. Int J Clin Pract 61:1256-1269

118. Sang CN, Ramadan NM, Wallihan RG, Chappell AS, Freitag FG, Smith TR, Silberstein SD, Johnson KW, Phebus LA, Bleakman D, Ornstein PL, Arnold B, Tepper SJ, Vandenhende F (2004) LY293558, a novel AMPA/GluR5 antagonist, is efficacious and well-tolerated in acute migraine. Cephalalgia 24:596-602

119. Saper J, Dahlof C, So Y, Tfelt-Hansen P, Malbecq W, Loeys T, Barraclough E, Klipfel M, Lines C, Visser H, Reines S, Yuen E (2006) Rofecoxib in the acute treatment of migraine: a randomized controlled clinical trial. Headache 46:264-275

120. Schoenen J, Pascual J, Rasmussen S, Sun W, Sikes C, Hettiarachchi J (2005) Patient preference for eletriptan $80 \mathrm{mg}$ versus subcutaneous sumatriptan $6 \mathrm{mg}$ : results of a crossover study in patients who have recently used subcutaneous sumatriptan. Eur J Neurol 12:108-117

121. Schoenen J, De KlippelN, Giurgea S, Herroelen L, Jacquy J, Louis P, Monseu G, Vandenheede M (2008) Almotriptan and its combination with aceclofenac for migraine attacks: a study of efficacy and the influence of auto-evaluated brush allodynia. Cephalalgia 28:1095-1105

122. Scholpp J, Schellenberg R, Moeckesch B, Banik N (2004) Early treatment of a migraine attack while pain is still mild increases the efficacy of sumatriptan. Cephalalgia 24:925-933

123. Schulman EA, Dermott KF (2003) Sumatriptan plus metoclopramide in triptan-non-responsive migraineurs. Headache 43:729-733

124. Sharma S, Prasad A, Nehru R, Anand KS, Rishi RK, Chaturvedi S, Bapna JS, Sharma DR (2002) Efficacy and tolerability of prochlorperazine buccal tablets in treatment of acute migraine. Headache 42:896-902

125. Sheftell F, Ryan R, Pitman V (2003) Efficacy, safety, and tolerability of oral eletriptan for treatment of acute migraine: a multicenter, double-blind, placebo-controlled study conducted in the United States. Headache 43:202-213

126. Sheftell FD, Dahlof CG, Brandes JL, Agosti R, Jones MW, Barrett PS (2005) Two replicate randomized, double-blind, placebo-controlled trials of the time to onset of pain relief in the acute treatment of migraine with a fast-disintegrating/ rapid-release formulation of sumatriptan tablets. Clin Ther 27:407-417

127. Silberstein S, Tepper S, Brandes J, Diamond M, Goldstein J, Winner P, Venkatraman S, Vrijens F, Malbecq W, Lines C, Visser WH, Reines S, Yuen E (2004) Randomized, placebo- controlled trial of rofecoxib in the acute treatment of migraine. Neurology 62:1552-1557

128. Silberstein SD, Young WB, Mendizabal JE, Rothrock JF, Alam AS (2003) Acute migraine treatment with droperidol: a randomized, double-blind, placebo-controlled trial. Neurology 60:315-321

129. Silberstein SD, Freitag FG, Rozen TD, Kudrow DB, Hewitt DJ, Jordan DM, Fisher AC, Rosenthal NR (2005) Tramadol/acetaminophen for the treatment of acute migraine pain: findings of a randomized, placebo-controlled trial. Headache 45:1317-1327

130. Silberstein SD, Mannix LK, Goldstein J, Couch JR, Byrd SC, Ames MH, McDonald SA, Lener SE, Toso C (2008) Multimechanistic (sumatriptan-naproxen) early intervention for the acute treatment of migraine. Neurology 71:114-121

131. Smith TR, Sunshine A, Stark SR, Littlefield DE, Spruill SE, Alexander WJ (2005) Sumatriptan and naproxen sodium for the acute treatment of migraine. Headache 45:983-991

132. Spierings EL, Rapoport AM, Dodick DW, Charlesworth B (2004) Acute treatment of migraine with zolmitriptan $5 \mathrm{mg}$ orally disintegrating tablet. CNS Drugs 18:1133-1141

133. Stark R, Dahlof C, Haughie S, Hettiarachchi J (2002) Efficacy, safety and tolerability of oral eletriptan in the acute treatment of migraine: results of a phase III, multicentre, placebo-controlled study across three attacks. Cephalalgia 22:23-32

134. Steiner TJ, Diener HC, MacGregor EA, Schoenen J, Muirheads N, Sikes CR (2003) Comparative efficacy of eletriptan and zolmitriptan in the acute treatment of migraine. Cephalalgia 23:942-952

135. Stronks DL, Tulen JH, Bussmann HB, Mulder LJ, Passchier J (2003) Effects of naratriptan versus naproxen on daily functioning in the acute treatment of migraine: a randomized, double-blind, double-dummy, crossover study. Headache 43:845-852

136. Sunshine A, Mulhern SA, Olson N, Elkind A, Almas M, Sikes C (2006) Comparative sensitivity of stopwatch methodology and conventional pain assessment measures for detecting early response to triptans in migraine: results of a randomized, openlabel pilot study. Clin Ther 28:1107-1115

137. Tanen DA, Miller S, French T, Riffenburgh RH (2003) Intravenous sodium valproate versus prochlorperazine for the emergency department treatment of acute migraine headaches: a prospective, randomized, double-blind trial. Ann Emerg Med $41: 847-853$

138. Tepper SJ, Cady R, Dodick D, Freitag FG, Hutchinson SL, Twomey C, Kuhn TA (2006) Oral sumatriptan for the acute treatment of probable migraine: first randomized, controlled study. Headache 46:115-124

139. Tfelt-Hansen P, Bach FW, Daugaard D, Tsiropoulos I, Riddersholm B (2006) Treatment with sumatriptan $50 \mathrm{mg}$ in the mild phase of migraine attacks in patients with infrequent attacks: a randomised, double-blind, placebo-controlled study. J Headache Pain 7:389-394

140. Tietjen GE, Athanas K, Utley C, Herial NA, Khuder SA (2005) The combination of naratriptan and prochlorperazine in migraine treatment. Headache 45:751-753

141. Tuchman M, Hee A, Emeribe U, Silberstein S (2006) Efficacy and tolerability of zolmitriptan oral tablet in the acute treatment of menstrual migraine. CNS Drugs 20:1019-1026

142. Vecsei L, Gallacchi G, Sagi I, Semjen J, Tajti J, Szok D, Muller M, Vadass P, Kerekgyarto M (2007) Diclofenac epolamine is effective in the treatment of acute migraine attacks. A randomized, crossover, double blind, placebo-controlled, clinical study. Cephalalgia 27:29-34

143. Vollono C, Capuano A, Mei D, Ferraro D, Pierguidi L, Evangelista M, Di TrapaniG (2005) Multiple attack study on the available triptans in Italy versus placebo. Eur $\mathrm{J}$ Neurol $12: 557-563$ 
144. Wang SJ, Fuh JL, Wu ZA (2007) Intranasal sumatriptan study with high placebo response in Taiwanese patients with migraine. J Chin Med Assoc 70:39-46

145. Wendt J, Cady R, Singer R, Peters K, Webster C, Kori S, Byrd S (2006) A randomized, double-blind, placebo-controlled trial of the efficacy and tolerability of a 4-mg dose of subcutaneous sumatriptan for the treatment of acute migraine attacks in adults. Clin Ther 28:517-526

146. Wentz AL, Jimenez TB, Dixon RM, Aurora SK, Gold M (2008) A double-blind, randomized, placebo-controlled, single-dose study of the cyclooxygenase-2 inhibitor, GW406381, as a treatment for acute migraine. Eur J Neurol 15:420-427

147. Winner P, Mannix LK, Putnam DG, McNeal S, Kwong J, O'Quinn S, Richardson MS (2003) Pain-free results with sumatriptan taken at the first sign of migraine pain: two randomized, double-blind, placebo-controlled studies. Mayo Clin Proc 78:1214-1222

148. Winner P, Adelman J, Aurora S, Lener ME, Ames M (2006) Efficacy and tolerability of sumatriptan injection for the treatment of morning migraine: two multicenter, prospective, randomized, double-blind, controlled studies in adults. Clin Ther 28:1582-1591

149. Anand KS, Prasad A, Singh MM, Sharma S, Bala K (2006) Botulinum toxin type A in prophylactic treatment of migraine. Am J Ther 13:183-187

150. Ashtari F, Shaygannejad V, Akbari M (2008) A double-blind, randomized trial of low-dose topiramate versus propranolol in migraine prophylaxis. Acta Neurol Scand 118:301-305

151. Aurora SK, Gawel M, Brandes JL, Pokta S, VanDenburgh AM (2007) Botulinum toxin type a prophylactic treatment of episodic migraine: a randomized, double-blind, placebo-controlled exploratory study. Headache 47:486-499

152. Bartolini M, Silvestrini M, Taffi R, Lanciotti C, Luconi R, Capecci M, Provinciali L (2005) Efficacy of topiramate and valproate in chronic migraine. Clin Neuropharmacol 28:277279

153. Blumenfeld AM, Schim JD, Chippendale TJ (2008) Botulinum toxin type A and divalproex sodium for prophylactic treatment of episodic or chronic migraine. Headache 48:210-220

154. Brandes JL, Saper JR, Diamond M, Couch JR, Lewis DW, Schmitt J, Neto W, Schwabe S, Jacobs D (2004) Topiramate for migraine prevention: a randomized controlled trial. JAMA 291:965-973

155. Brandes JL, Visser WH, Farmer MV, Schuhl AL, Malbecq W, Vrijens F, Lines CR, Reines SA (2004) Montelukast for migraine prophylaxis: a randomized, double-blind, placebocontrolled study. Headache 44:581-586

156. Bulut S, Berilgen MS, Baran A, Tekatas A, Atmaca M, Mungen B (2004) Venlafaxine versus amitriptyline in the prophylactic treatment of migraine: randomized, double-blind, crossover study. Clin Neurol Neurosurg 107:44-48

157. Diener HC, Matias-Guiu J, Hartung E, Pfaffenrath V, Ludin HP, Nappi G, De Beukelaar F (2002) Efficacy and tolerability in migraine prophylaxis of flunarizine in reduced doses: a comparison with propranolol $160 \mathrm{mg}$ daily. Cephalalgia 22:209-221

158. Diener HC, Tfelt-Hansen P, Dahlof C, Lainez MJ, Sandrini G, Wang SJ, Neto W, Vijapurkar U, Doyle A, Jacobs D (2004) Topiramate in migraine prophylaxis-results from a placebocontrolled trial with propranolol as an active control. J Neurol 251:943-950

159. Diener HC, Pfaffenrath V, Schnitker J, Friede M, Henneickevon Zepelin HH (2005) Efficacy and safety of $6.25 \mathrm{mg}$ t.i.d. feverfew CO2-extract (MIG-99) in migraine prevention-a randomized, double-blind, multicentre, placebo-controlled study. Cephalalgia 25:1031-1041
160. Diener HC, Bussone G, Van Oene JC, Lahaye M, Schwalen S, Goadsby PJ (2007) Topiramate reduces headache days in chronic migraine: a randomized, double-blind, placebo-controlled study. Cephalalgia 27:814-823

161. Diener HC, Agosti R, Allais G, Bergmans P, Bussone G, Davies B, Ertas M, Lanteri-Minet M, Reuter U, Del Rio MS, Schoenen J, Schwalen S, van Oene J (2007) Cessation versus continuation of 6-month migraine preventive therapy with topiramate (PROMPT): a randomised, double-blind, placebo-controlled trial. Lancet Neurol 6:1054-1062

162. Donaldson D, Sundermann R, Jackson R, Bastani A (2008) Intravenous dexamethasone versus placebo as adjunctive therapy to reduce the recurrence rate of acute migraine headaches: a multicenter, double-blinded, placebo-controlled randomized clinical trial. Am J Emerg Med 26:124-130

163. Elkind AH, O'Carroll P, Blumenfeld A, DeGryse R, Dimitrova $R$ (2006) A series of three sequential, randomized, controlled studies of repeated treatments with botulinum toxin type A for migraine prophylaxis. J Pain 7:688-696

164. Evers S, Vollmer-Haase J, Schwaag S, Rahmann A, Husstedt IW, Frese A (2004) Botulinum toxin A in the prophylactic treatment of migraine-a randomized, double-blind, placebocontrolled study. Cephalalgia 24:838-843

165. Freitag FG, Collins SD, Carlson HA, Goldstein J, Saper J, Silberstein S, Mathew N, Winner PK, Deaton R, Sommerville K (2002) A randomized trial of divalproex sodium extended-release tablets in migraine prophylaxis. Neurology 58:1652-1659

166. Freitag FG, Diamond S, Diamond M, Urban G (2008) Botulinum toxin type $\mathrm{A}$ in the treatment of chronic migraine without medication overuse. Headache 48:201-209

167. Guidotti M, Mauri M, Barrila C, Guidotti F, Belloni C (2007) Frovatriptan versus transdermal oestrogens or naproxen sodium for the prophylaxis of menstrual migraine. J Headache Pain 8:283-288

168. Gupta P, Singh S, Goyal V, Shukla G, Behari M (2007) Lowdose topiramate versus lamotrigine in migraine prophylaxis (the Lotolamp study). Headache 47:402-412

169. Keskinbora K, Aydinli I (2008) A double-blind randomized controlled trial of topiramate and amitriptyline either alone or in combination for the prevention of migraine. Clin Neurol Neurosurg 110:979-984

170. Lipton RB, Gobel H, Einhaupl KM, Wilks K, Mauskop A (2004) Petasites hybridus root (butterbur) is an effective preventive treatment for migraine. Neurology 63:2240-2244

171. MacGregor EA, Hackshaw A (2002) Prevention of migraine in the pill-free interval of combined oral contraceptives: a doubleblind, placebo-controlled pilot study using natural oestrogen supplements. J Fam Plann Reprod Health Care 28:27-31

172. MacGregor EA, Frith A, Ellis J, Aspinall L, Hackshaw A (2006) Prevention of menstrual attacks of migraine: a double-blind placebo-controlled crossover study. Neurology 67:2159-2163

173. Magis D, Ambrosini A, Sandor P, Jacquy J, Laloux P, Schoenen J (2007) A randomized double-blind placebo-controlled trial of thioctic acid in migraine prophylaxis. Headache 47:52-57

174. Maizels M, Blumenfeld A, Burchette R (2004) A combination of riboflavin, magnesium, and feverfew for migraine prophylaxis: a randomized trial. Headache 44:885-890

175. Mannix LK, Savani N, Landy S, Valade D, Shackelford S, Ames MH, Jones MW (2007) Efficacy and tolerability of naratriptan for short-term prevention of menstrually related migraine: data from two randomized, double-blind, placebo-controlled studies. Headache 47:1037-1049

176. Mei D, Capuano A, Vollono C, Evangelista M, Ferraro D, Tonali P, Di Trapani G (2004) Topiramate in migraine prophylaxis: a randomised double-blind versus placebo study. Neurol Sci 25:245-250 
177. Millan-Guerrero RO, Pineda-Lucatero AG, Hernandez-Benjamin T, Tene CE, Pacheco MF (2003) Nalpha-methylhistamine safety and efficacy in migraine prophylaxis: phase I and phase II studies. Headache 43:389-394

178. Millan-Guerrero RO, Isais-Millan R, Benjamin TH, Tene CE (2006) Nalpha-methyl histamine safety and efficacy in migraine prophylaxis: phase III study. Can.J Neurol.Sci. 33:195-199

179. Millan-Guerrero RO, Isais-Millan R, Barreto-Vizcaino S, Rivera-Castano L, Garcia-Solorzano A, Lopez-Blanca C, Membrila-Maldonado M, Munoz-Solis R (2007) Subcutaneous histamine versus sodium valproate in migraine prophylaxis: a randomized, controlled, double-blind study. Eur J Neurol 14:1079-1084

180. Millan-Guerrero RO, Isais-Millan R, Barreto-Vizcaino S, Gutierrez I, Rivera-Castano L, Trujillo-Hernandez B, Baltazar LM (2008) Subcutaneous histamine versus topiramate in migraine prophylaxis: a double-blind study. Eur Neurol 59:237-242

181. Pfaffenrath V, Diener HC, Fischer M, Friede M, Henneicke-von Zepelin HH (2002) The efficacy and safety of Tanacetum parthenium (feverfew) in migraine prophylaxis - a double-blind, multicentre, randomized placebo-controlled dose-response study. Cephalalgia 22:523-532

182. Pradalier A, Lanteri-Minet M, Geraud G, Allain H, Lucas C, Delgado A (2004) The PROMISE study: PROphylaxis of MIgraine with SEglor (dihydroergotamine mesilate) in French primary care. CNS Drugs 18:1149-1163

183. Relja M, Poole AC, Schoenen J, Pascual J, Lei X, Thompson C (2007) A multicentre, double-blind, randomized, placebo-controlled, parallel group study of multiple treatments of botulinum toxin type A (BoNTA) for the prophylaxis of episodic migraine headaches. Cephalalgia 27:492-503

184. Sandor PS, Di Clemente L, Coppola G, Saenger U, Fumal A, Magis D, Seidel L, Agosti RM, Schoenen J (2005) Efficacy of coenzyme Q10 in migraine prophylaxis: a randomized controlled trial. Neurology 64:713-715

185. Saper JR, Mathew NT, Loder EW, DeGryse R, VanDenburgh AM (2007) A double-blind, randomized, placebo-controlled comparison of botulinum toxin type A injection sites and doses in the prevention of episodic migraine. Pain Med 8:478-485

186. Schellenberg R, Lichtenthal A, Wohling H, Graf C, Brixius K (2008) Nebivolol and metoprolol for treating migraine: an advance on beta-blocker treatment? Headache 48:118-125

187. Shaygannejad V, Janghorbani M, Ghorbani A, Ashtary F, Zakizade N, Nasr V (2006) Comparison of the effect of topiramate and sodium valporate in migraine prevention: a randomized blinded crossover study. Headache 46:642-648

188. Silberstein S, Saper J, Berenson F, Somogyi M, McCague K, D'Souza J (2008) Oxcarbazepine in migraine headache: a double-blind, randomized, placebo-controlled study. Neurology 70:548-555

189. Silberstein SD, Elkind AH, Schreiber C, Keywood C (2004) A randomized trial of frovatriptan for the intermittent prevention of menstrual migraine. Neurology 63:261-269

190. Silberstein SD, Neto W, Schmitt J, Jacobs D (2004) Topiramate in migraine prevention: results of a large controlled trial. Arch Neurol 61:490-495

191. Silberstein SD, Hulihan J, Karim MR, Wu SC, Jordan D, Karvois D, Kamin M (2006) Efficacy and tolerability of topiramate $200 \mathrm{mg} /$ day in the prevention of migraine with/without aura in adults: a randomized, placebo-controlled, double-blind, 12-week pilot study. Clin Ther 28:1002-1011

192. Silberstein SD, Lipton RB, Dodick DW, Freitag FG, Ramadan N, Mathew N, Brandes JL, Bigal M, Saper J, Ascher S, Jordan DM, Greenberg SJ, Hulihan J (2007) Efficacy and safety of topiramate for the treatment of chronic migraine: a randomized, double-blind, placebo-controlled trial. Headache 47:170-180

193. Togha M, Rahmat Jirde M, Nilavari K, Ashrafian H, Razeghi S, Kohan L (2008) Cinnarizine in refractory migraine prophylaxis: efficacy and tolerability. A comparison with sodium valproate. J Headache Pain 9:77-82

194. Tronvik E, Stovner LJ, Helde G, Sand T, Bovim G (2003) Prophylactic treatment of migraine with an angiotensin II receptor blocker: a randomized controlled trial. JAMA 289:6569

195. Tuchman MM, Hee A, Emeribe U, Silberstein S (2008) Oral zolmitriptan in the short-term prevention of menstrual migraine: a randomized, placebo-controlled study. CNS Drugs 22:877886

196. Vo AH, Satori R, Jabbari B, Green J, Killgore WD, Labutta R, Campbell WW (2007) Botulinum toxin type-A in the prevention of migraine: a double-blind controlled trial. Aviat Space Environ Med 78:B113-B118

197. Von Seggern RL, Mannix LK, Adelman JU (2004) Rofecoxib in the prevention of perimenstrual migraine: an open-label pilot trial. Headache 44:160-165

198. Wammes-van der Heijden EA, Smidt MH, Tijssen CC, van't Hoff AR, Lenderink AW, Egberts AC (2005) Effect of lowintensity acenocoumarol on frequency and severity of migraine attacks. Headache 45:137-143

199. Pilgrim AJ (1991) Methodology of clinical trials of sumatriptan in migraine and cluster headache. Eur Neurol 31:295-299

200. Prior MJ, Codispoti JR, Fu M (2010) A randomized, placebocontrolled trial of acetaminophen for treatment of migraine headache. Headache 50:819-833

201. Davies GM, Santanello N, Lipton R (2000) Determinants of patient satisfaction with migraine therapy. Cephalalgia 20:554-560

202. Lipton RB, Stewart WF (1999) Acute migraine therapy: do doctors understand what patients with migraine want from therapy? Headache 39:20-26

203. Bendtsen L, Mattsson P, Zwart JA, Lipton RB (2003) Placebo response in clinical randomized trials of analgesics in migraine. Cephalalgia 23:487-490

204. Peres MF, Silberstein S, Moreira F, Corchs F, Vieira DS, Abraham N, Gebeline-Myers C (2007) Patients' preference for migraine preventive therapy. Headache 47:540-545

205. Sorensen PS, Hansen K, Olesen J (1986) A placebo-controlled, double-blind, cross-over trial of flunarizine in common migraine. Cephalalgia 6:7-14

206. Bendtsen L, Bigal ME, Cerbo R, Diener HC, Holroyd K, Lampl C, Mitsikostas DD, Steiner TJ, Tfelt-Hansen P (2009) Guidelines for controlled trials of drugs in tension-type headache: second edition. Cephalalgia

207. Olesen J, Krabbe AA, Tfelt-Hansen P (1981) Methodological aspects of prophylactic drug trials in migraine. Cephalalgia $1: 127-141$

208. Hauge AW, Hougaard A, Olesen J (2010) On the methodology of drug trials in migraine with aura. Cephalalgia 30:1041-1048 